\title{
Letter to the editor: Increase of influenza vaccination coverage rates during the COVID-19 pandemic and implications for the upcoming influenza season in northern hemisphere countries and Australia
}

\author{
Marco Del Riccio ${ }^{1,2}$, Bruno Lina ${ }^{3}$, Saverio Caini ${ }^{1}$, Lisa Staadegaard ${ }^{1}$, Sytske Wiegersma ${ }^{1}$, Jan Kynčl ${ }^{4}$, Béhazine Combadière ${ }^{5}$ \\ Chandini Raina MacIntyre ${ }^{6}$, John Paget ${ }^{1}$ \\ 1. Netherlands Institute for Health Services Research (Nivel), Utrecht, Netherlands \\ 2. Postgraduate School in Hygiene and Preventive Medicine, University of Florence, Florence, Italy \\ 3. VirPath Laboratory, University of Lyon, Lyon, France \\ 4. Department of Infectious Diseases Epidemiology, National Institute of Public Health, Prague, Czech Republic \\ 5. Inserm, Centre d'Immunologie et des Maladies Infectieuses, Sorbonne Université, France \\ 6. Kirby Institute, University of New South Wales, Sydney, New South Wales, Australia
}

Correspondence: Marco Del Riccio (M.delRiccio@Nivel.nl)

Citation style for this article:

Del Riccio Marco, Lina Bruno, Caini Saverio, Staadegaard Lisa, Wiegersma Sytske, Kynčl Jan, Combadière Béhazine, Maclntyre Chandini Raina, Paget John. Letter to the editor: Increase of influenza vaccination coverage rates during the COVID-19 pandemic and implications for the upcoming influenza season in northern hemisphere countries and Australia. Euro Surveill. 2021;26(50):pii=2101143. https://doi.org/10.2807/1560-7917.ES.2021.26.50.2101143

To the editor: We read with interest the collection of articles 'Spotlight influenza 2021' recently published in Eurosurveillance [1]. This collection highlights some important features of the unusual 2020/21 northern hemisphere influenza season and the accompanying editorial recommends preparedness measures for the upcoming 2021/22 season [2]. The authors suggest that vaccination may have contributed to the low influenza circulation in $2020 / 21$ and use the example of Spain where influenza vaccination coverage rates (VCRs) increased across different target groups during the 2020/21 winter [2]. We would like to bring further evidence regarding this point by providing VCR data published by 10 northern hemisphere countries and Australia (Table), with a particular focus on elderly people.

During the 2020/21 winter, influenza VCRs in elderly people increased in England (+8.5\%), France $(+7.9 \%)$, Israel $(+8.4 \%)$, Italy $(+10.7 \%)$, the Netherlands, $(+6.6 \%)$, the Philippines $(+3.0 \%)$, Poland $(+3.3 \%)$, Spain $(+13.0 \%)$, and the United States (US) $(+5.4 \%)$, compared with 2019/20 (Table). Remarkably, England and the US managed to reach coverage rates of $75 \%$ in this population group, which is recommended by the World Health Organization (WHO) and the EU Council Recommendation 2009/1019/EU [3,4]. A decrease in VCRs was instead observed in South Korea (from 83.8\% to $73.6 \%$ ): this is likely related to a report of alleged influenza vaccine-related deaths that attracted considerable media attention in 2020 [5]. Of note, VCRs in most of these northern hemisphere countries remained generally stable in previous winters (Table). In the southern hemisphere, influenza VCRs in elderly people increased in Australia by $9.0 \%$ in 2020 compared with 2019. A further, slight increase was observed in 2021, while decreases were seen in other age groups [6]. These declines were possibly due to the convergence of influenza and coronavirus disease (COVID-19) vaccinations in 2021, with guidelines to space these apart by at least 2 weeks.

There has been very little influenza activity around the world since April 2020 [7] and it is difficult to anticipate influenza circulation in the upcoming winter. Current modelling scenarios range from a mild season to a large increase in cases, mainly depending on the extent of the use of non-pharmaceutical interventions (NPIs) [8]. The emergence of the acute respiratory syndrome coronavirus 2 (SARS-CoV-2) Omicron variant of concern means there will likely be a continuation of containment measures related to the COVID-19 pandemic - such as physical distancing, recommendations to wear face masks, and movement restrictions - which could result in late or little influenza virus activity in the northern hemisphere. We agree with Larrauri and Prosenc [2] that the recent low levels of influenza activity may lead to an increased proportion of susceptibles and predispose to severe epidemics at some point, so achieving high influenza VCRs will be crucial to contain the influenza burden, especially when NPIs are relaxed. Finally, strengthening influenza VCR monitoring in different population groups [9] will be critical to ensure that we are achieving - or at least approaching - the objectives we set for influenza prevention and control. 
Influenza VCRs in the elderly by influenza season and difference between the first COVID-19 pandemic and the prepandemic season in 10 northern hemisphere countries and 1 southern hemisphere country, 2017/18 to 2020/21

\begin{tabular}{|c|c|c|c|c|c|c|c|}
\hline \multicolumn{8}{|c|}{ Northern hemisphere countries } \\
\hline Country & $\begin{array}{c}\text { Age } \\
\text { (years) }\end{array}$ & $\begin{array}{l}2017 / 18 \\
\text { VCR (\%) }\end{array}$ & $\begin{array}{l}2018 / 19 \\
\text { VCR }(\%)\end{array}$ & $\begin{array}{l}2019 / 20 \\
\text { VCR }(\%)\end{array}$ & $\begin{array}{l}2020 / 21 \\
\text { VCR }(\%)\end{array}$ & $\begin{array}{c}2019 / 20-2020 / 21 \\
\text { difference }(\%)\end{array}$ & Source \\
\hline England & \multirow{5}{*}{$\geq 65$} & 73.0 & 72.0 & 72.4 & 80.9 & +8.5 & Public Health England \\
\hline France & & 49.7 & 51.0 & 52.0 & 59.9 & +7.9 & Public Health France \\
\hline Israel & & 59.8 & 59.2 & 59.8 & 68.2 & +8.4 & $\begin{array}{l}\text { Ministry of Health, Israel; Organisation } \\
\text { for Economic Co-operation and } \\
\text { Development (OECD), France }\end{array}$ \\
\hline Italy & & 52.7 & 53.1 & 54.6 & 65.3 & +10.7 & Ministry of Health, Italy \\
\hline The Netherlands & & 60.4 & 60.3 & 61.3 & 67.9 & +6.6 & $\begin{array}{l}\text { The Netherlands Institute for Health } \\
\text { Services Research (Nivel) }\end{array}$ \\
\hline Philippines $^{\mathrm{a}}$ & $\geq 60$ & NA & NA & 2.6 & 5.6 & +3.0 & Ministry of Health, Philippines \\
\hline Poland & \multirow{4}{*}{$\geq 65$} & 13.0 & 14.2 & 15.1 & 18.4 & +3.3 & $\begin{array}{l}\text { National Institute of Public Health, } \\
\text { Poland }\end{array}$ \\
\hline South Korea & & 81.3 & 82.8 & 83.8 & 73.6 & -10.2 & $\begin{array}{l}\text { Korea Disease Control and Prevention } \\
\text { Agency, reported by Kwon Y et al. [5] }\end{array}$ \\
\hline Spain & & $55 \cdot 7$ & $54 \cdot 3$ & $54 \cdot 7$ & 67.7 & +13.0 & Ministry of Health, Spain \\
\hline United States & & 59.6 & 68.1 & 69.8 & 75.2 & +5.4 & $\begin{array}{l}\text { Centers for Disease Control and } \\
\text { Prevention (CDC) }\end{array}$ \\
\hline \multicolumn{8}{|c|}{ Southern hemisphere country } \\
\hline Country & $\begin{array}{c}\text { Age } \\
\text { (years) }\end{array}$ & $\begin{array}{l}2017 \text { VCR } \\
(\%)\end{array}$ & $\begin{array}{l}2018 \text { VCR } \\
(\%)\end{array}$ & $\begin{array}{l}2019 \text { VCR } \\
(\%)\end{array}$ & $\begin{array}{c}2020 \\
\text { VCR (\%) }\end{array}$ & $\begin{array}{c}2019-2020 \\
\text { difference (\%) }\end{array}$ & Source \\
\hline Australia & $\geq 65$ & 33.6 & 50.4 & 60.6 & 69.6 & +9.0 & Department of Health, Australia \\
\hline
\end{tabular}

VCR: vaccination coverage rate; NA: not available.

a The Philippines is a tropical climate country with influenza activity occurring from June to November, and the vaccine is administrated from February on each year.

\section{Acknowledgements}

We thank the colleagues associated with the FluCov project, including the funders. We also thank the members of the Global Influenza Initiative (GII).

Funding: The Nivel authors were funded by a collaborative research agreement between Sanofi Pasteur and Nivel; the funder had no role in writing this letter to the editor.

\section{Conflict of interest}

MDR, BL, SC, LS, SW, JK, BC and CRM declare no competing interests. JP declares that Nivel has received influenza research grants from the World Health Organization, Sanofi Pasteur, and the Foundation for Influenza Epidemiology.

\section{Authors' contributions}

All authors contributed to the conceptualisation and drafting of this Letter.

\section{References}

1. Eurosurveillance. Spotlight influenza 2021. [Accessed: 9 Dec 2021]. Available from: https://www.eurosurveillance.org/ content/spotlight-influenza-2021

2. Larrauri A, Prosenc Trilar K. Preparing for an influenza season $2021 / 22$ with a likely co-circulation of influenza virus and SARS-CoV-2. Euro Surveill. 2021;26(41):2100975. https://
doi.org/10.2807/1560-7917.ES.2021.26.41.2100975 PMID: 34651574

3. World Health Organization Regional Office for Europe (WHO/Europe). Influenza vaccination coverage and effectiveness. Copenhagen: WHO/Europe. [Accessed: Oct 2021]. Available from: https://www.euro.who.int/en/healthtopics/communicable-diseases/influenza/vaccination/ influenza-vaccination-coverage-and-effectiveness

4. Council of the European Union. Council Recommendation of 22 December 2009 on seasonal influenza vaccination (2009/1019/ EU). Official Journal of the European Union. 2009. L 348/71. [Accessed: Dec 2021]. Available from: http://eur-lex.europa. eu/LexUriServ/LexUriServ.do?uri=0J:L:2009:348:0071:0072: E N:PDF

5. Kwon Y, Choe YJ, Yun JW, Kim HK, Kim S, Chun C, et al. Impact of Media Coverage on Influenza Vaccine Coverage in Elderly Individuals from 2020 to 2021 in the Republic of Korea. Vaccines (Basel). 2021;9(4):367. https://doi.org/10.3390/ vaccines9040367 PMID: 33920117

6. Australian Government. Department of Health. Influenza (flu) immunization data. Canberra: Australian Government. Department of Health. [Accessed: Oct 2021]. Available from: https://www.health.gov.au/resources/publications/ influenza-flu-immunisation-data

7. Burki TK. Circulation of influenza, RSV, and SARS-CoV-2: an uncertain season ahead. Lancet Respir Med. 2021;9(10):e103. https://doi.org/10.1016/S2213-2600(21)00364-7 PMID: 34370976

8. Baker RE, Park SW, Yang W, Vecchi GA, Metcalf CJE, Grenfell BT. The impact of COVID-19 nonpharmaceutical interventions on the future dynamics of endemic infections. Proc Natl Acad Sci USA. 2020;117(48):30547-53. https://doi.org/10.1073/ pnas.2013182117 PMID: 33168723

9. European Centre for Disease Prevention and Control (ECDC). Seasonal influenza vaccination in EU/EEA Member States. Stockholm: ECDC. [Accessed: Nov 2021]. Available from: https://www.ecdc.europa.eu/sites/default/files/documents/ seasonal-influenza-antiviral-use-2018.pdf 
License, supplementary material and copyright

This is an open-access article distributed under the terms of the Creative Commons Attribution (CC BY 4.0) Licence. You may share and adapt the material, but must give appropriate credit to the source, provide a link to the licence and indicate if changes were made.

Any supplementary material referenced in the article can be found in the online version.

This article is copyright of the authors or their affiliated institutions, 2021. 